\title{
Mycobacterium avium complex infection mimicking lung cancer
}

\author{
Hideharu Hagiya ${ }^{\circ}$
}

Department of General Internal Medicine, Osaka University Hospital, Suita, Osaka, Japan

Correspondence to Dr Hideharu Hagiya, e_dai_for_all@hotmail.com

Accepted 3 February 2019

D) Check for updates

(c) BMJ Publishing Group Limited 2019. No commercial re-use. See rights and permissions. Published by BMJ.

To cite: Hagiya H. BMJ Case Rep 2019;12:e228847. doi:10.1136/bcr-2018228847

\section{DESCRIPTION}

A 65 -year-old man presented with chest discomfort. He had no history of smoking and did not have any respiratory symptoms either. Physical examination did not reveal any specific findings. Lung CT demonstrated an irregularly margined and lobulated lesion $(22 \times 20 \mathrm{~mm})$ in the left lower lobe that was partially contrast enhanced (figure $1 \mathrm{~A}, \mathrm{~B}$ ). Although the results of serum tumour markers and transbronchial needle aspiration were inapparent, ${ }^{18} \mathrm{~F}$-fluorodeoxyglucose positron emission tomography-CT showed a high uptake (maximum standardized uptake value [SUVmax] 5.6) indicating malignancy (figure 1C). A left lower lobectomy was performed by video-assisted thoracic surgery. Subsequent histopathological examination confirmed the presence of a non-caseating granuloma containing multinucleated giant cells. The results of PCR and culture revealed the lesion to be caused by Mycobacterium avium complex infection.

Non-tuberculous mycobacteria can manifest as a solitary pulmonary nodule mimicking lung tumour. The lesion may not have any specific clinical or

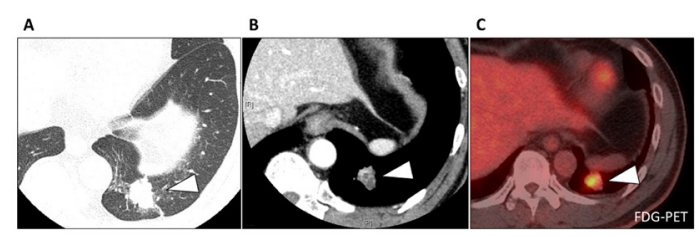

Figure 1 Plain (A), contrast-enhanced (B) and ${ }^{18} \mathrm{~F}$-fluorodeoxyglucose-positron emission (C) CT of the lung.

\section{Learning points}

- Pulmonary non-tuberculous mycobacteria infection imitates lung cancer in radiological findings.

- Surgical resection followed by pathological investigations is required to arrive at the diagnosis.

- Positive findings in PET scans do not necessarily indicate malignancy as similar findings can be observed in inflammatory disorders.

radiological characteristics. ${ }^{1}$ Invasive procedures including surgical resection of the lung may be required to arrive at the definitive diagnosis. ${ }^{2}$

Contributors $\mathrm{HH}$ wrote the manuscript.

Funding The authors have not declared a specific grant for this research from any funding agency in the public, commercial or not-for-profit sectors.

Competing interests None declared.

Patient consent for publication Obtained.

Provenance and peer review Not commissioned; externally peer reviewed.

\section{REFERENCES}

1 Kobashi Y, Fukuda M, Yoshida K, et al. Four cases of pulmonary Mycobacterium avium intracellulare complex presenting as a solitary pulmonary nodule and a review of other cases in Japan. Respirology 2006;11:317-21.

2 Asakura T, Ishii M, Haraguchi M, et al. Dry pleurisy complicating solitary pulmonary nodules caused by Mycobacterium avium: a case report. J Med Case Rep 2015;9:238.
Copyright 2019 BMJ Publishing Group. All rights reserved. For permission to reuse any of this content visit https://www.bmj.com/company/products-services/rights-and-licensing/permissions/

BMJ Case Report Fellows may re-use this article for personal use and teaching without any further permission.

Become a Fellow of BMJ Case Reports today and you can:

- Submit as many cases as you like

- Enjoy fast sympathetic peer review and rapid publication of accepted articles

- Access all the published articles

- Re-use any of the published material for personal use and teaching without further permission

For information on Institutional Fellowships contact consortiasales@bmjgroup.com

Visit casereports.bmj.com for more articles like this and to become a Fellow 